\title{
Formation of 5-Fluoromethylfurfural from 5-Halomethylfurfurals Catalyzed by Crown Ethers
}

\author{
Mikhail Yu. Chernyak ${ }^{a}$, Valery E. Tarabanko ${ }^{\mathrm{a}, \mathrm{b} *}$, \\ Andrey A. Morozova and Alexander A. Kondrasenko ${ }^{a}$ \\ anstitute of Chemistry and Chemical Technology SB RAS \\ 50/24 Akademgorodok, Krasnoyarsk, 660036, Russia \\ ${ }^{b}$ Siberian Federal University \\ 79 Svobodny, Krasnoyarsk, 660041, Russia
}

Received 28.12.2014, received in revised form 16.02.2015, accepted 03.03.2015

5-fluoromethylfurfural has been obtained by interaction of 5-bromo- and 5-chloromethylfurfurals with potassium bifluoride in the presence of dibenzo-24-crown-8 and 18-crown-6 in acetonitrile medium. The yield attains 40-60 mol. \%, and the selectivity of 5-bromomethylfurfural conversion is close to $90 \%$. The NMR and MS spectra are described. The results demonstrate the capability of the $\mathrm{KHF}_{2} /$ crown-ethers system to process biomass-derived feedstock molecules to valuable furan compounds by exchange reactions.

Keywords: 5-fluoromethylfurfural, 5-bromomethylfurfrural, 5-chloromethylfurfrural, 18-crown-6, dibenzo-24-crown-8.

(c) Siberian Federal University. All rights reserved

* Corresponding author E-mail address: veta@icct.ru 


\title{
Получение 5-фторметилфурфурола
}

\section{из 5-галогенметилфурфуролов \\ в присутствии краун-эфиров}

\author{
М.Ю. Черняка ${ }^{\mathrm{a}}$ В.Е. Тарабанько ${ }^{\mathrm{a}, \boldsymbol{\sigma}}$, \\ А.А. Морозов ${ }^{\text {a }}$ А.А. Кондрасенко \\ ${ }^{a}$ Институт химии и химической технологии СО РАН \\ Россия, 660036, Красноярск, Академгородок, 50/24 \\ ${ }^{6}$ Сибирский федеральный университет \\ Россия, 660041, Красноярск, пр. Свободный, 79
}

Изучен селективный процесс получения 5-фторметилфурфурола путем взаимодействия 5-бром и 5-хлорметилфурфуролов с гидрофторидом калия в присутствии дибензо-24-каун-8 и 18-краун-6 эфиров в среде ацетонитрила. Выход продукта реакиии достигает 40-60 мол. \%. Приведены ЯМР 1 и масс-спектр продукта. Полученные результаты демонстрируют возможность применения системы КНF2/краун-эфир для получения высокореакционных фурановых соединений из возобновляемого сырья.

Ключевые слова: 5-фторметилфурфурол, 5-бромметилфурфурол, 5-хлорметилфурфурол, 18-краун-6, дибензо-24-краун-8.

\section{Introduction}

Carbohydrates are the only and practically unlimited source of furan compounds, such as 5-hydroxymethylfurfural (5-HMF), 5-chloro- and 5-bromomethylfurfural (5-CMF and 5-BMF). Fluoro-derivatives of furan compounds may have biologic activity [1-3], and therefore synthesis of such compounds is of great interest. 5-trifluoromethylfurfural was synthesised by interaction of furfural with trifluoroacetic acid and xenon difluoride [1]. 5-fluoromethylfurfural (5-FMF) might be commercially available [4], but promising synthetic methods for its production are not described in literature. Predicted properties of 5-FMF are generated using the ACD/Labs' ACD/PhysChem Suite and presented in [5].

Low nucleophility of fluoride ion along with low solubility of 5-halomethylfurfurals (5-HalMF) do not allow to obtain acceptable yield of 5-FMF by ion exchange between silver fluoride and 5-HalMF in water. The highest yields for this exchange reaction (5-10 mol. \%) were observed in the 5-BMF toluene - silver fluoride heterogeneous system [6]. The main products of such process were various isomers from alkylation of toluene by 5 -BMF.

In order to increase nucleophilic strength of fluoride ion in fluorination reactions, crown ethers as the mass transfer catalysts are widely used $[8,9,10]$. Despite these advances, such approaches have not been applied to synthesise 5-FMF from 5-HalMF.

The goal of the present paper is to study a formation of 5-FMF by action of potassium bifluoride on 5-HalMF in the presence of crown ethers. 
<smiles>O=C(O)C(=O)OCc1ccc(COCc2ccc(CF)o2)o1</smiles>

$\mathrm{Hal}: \mathrm{Cl}$ or $\mathrm{Br}$

\section{Experimental}

5-BMF and 5-CMF were synthesised according to [10, 11]. Dibenzo-24-crown-8 and 18-crown-6 from ACROS organics (USA, New Jersey), $\mathrm{KHF}_{2}$ and acetonitrile from «Khimreaktivsnab» (Russia, Bashkortostan, Ufa) were used in this study. $200 \mathrm{~mL}$ of acetonitrile was mixed with 5-HalMF (0.01 mol), crown ether $(0.005 \mathrm{~mol})$, and potassium bifluoride $(0.1 \mathrm{~mol})$. The reaction proceeded for $20-50$ hours at $80{ }^{\circ} \mathrm{C}$ with constant stirring to intensify the interphase ion exchange. The substrate consumption and the product accumulation were monitored by gas chromatography (Chromatec Kristall 2000M). After reaction the organic phase was filtered, evaporated at normal pressure, and the residue was distilled under vacuum (1-2 mm Hg). The product was identified by GC-MS and NMR. NMR spectra were recorded with a Bruker Avance III $600 \mathrm{MHz}$ spectrometer (Centre for Collective Use, Krasnoyarsk Scientific Centre SB RAS) with reference to the signal from the deuterated solvent. GC-MS study was carried out with an Agilent 7890A unit.

\section{Results and discussion}

Acetonitrile is a convenient aprotic solvent used for ion exchange reactions mediated by crown ethers [7, 8]. Increasing the crown ether to 5-HalMF molar ratio from 1:8 to 1:5 had almost no effect on the reaction rate. The reaction is highly selective, and 5-FMF is the only detectable product. The dependence graph of the substrate and the product concentrations versus reaction time is presented in Fig. 1.

After approx. 35 hours of reaction a half of the substrate is transformed; after this 5-FMF stops accumulating while concentration of 5-BMF continues to decline. The maximum product yield attains $0,8 \mathrm{~g}$ (42 mol. \%).

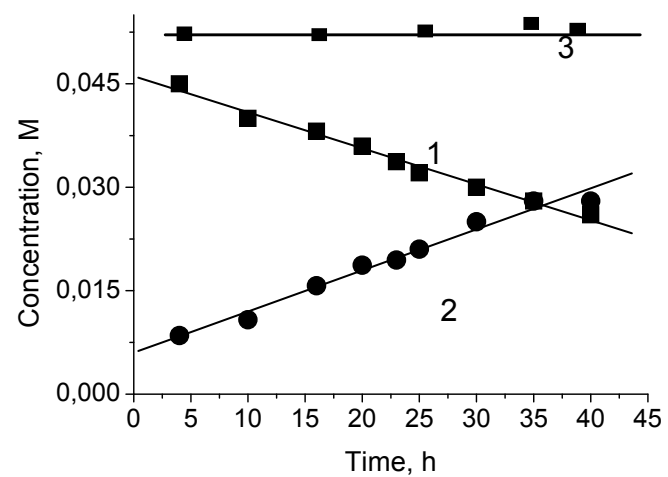

Fig. 1. Dependence of 5-fluoromethylfurfural concentrations versus time. $80^{\circ} \mathrm{C}, 0.01 \mathrm{M}$ dibenzo-24-crown- 8 . (1) - 5-bromomethylfurfural (initial concentration $0.052 \mathrm{M}$ ); (2) - 5-fluoromethylfurfural; (3) - the sum of 5-BMF and 5-FMF concentrations 
The data on reactivity of 18-crown- 6 in the same process under the similar conditions are shown in Fig. 2, and a rate of the process estimated by the substrate half-life is of seven times more as compared with dibenzo-24-crown-8 catalyzed process (Fig. 1). 18-crown-6 functions as a ligand for some metal cations with a particular affinity for potassium cations, and this affinity causes high rate of the process. Maximum analytic yield of 5-FMF obtained in the process catalyzed by 18 -crown- 6 attains value of $60 \mathrm{~mol} . \%$.

5-CMF is less reactive as a substrate for the 5-FMF synthesis. Fig.ure 3 shows the kinetics of consumption of 5-CMF and formation of 5-FMF. The 5-CMF half-life is of appr. 20 hours, and the product analytic yield does not exceed $40 \mathrm{~mol}$. \%.

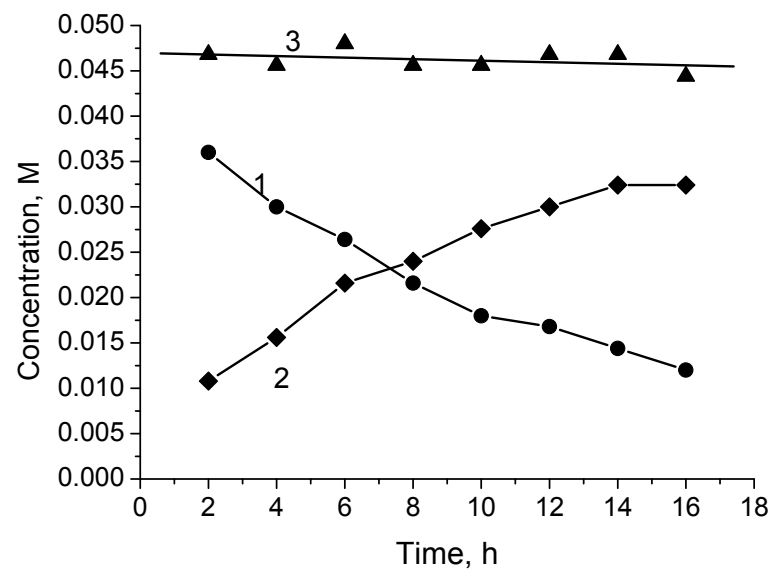

Fig. 2. Dependence of 5-fluoromethylfurfural concentrations versus time. $80^{\circ} \mathrm{C}, 0.01 \mathrm{M} 18$-crown- 6 concentration. (1) - 5-bromomethylfurfural (initial concentration $0.05 \mathrm{M}$ ); (2) - 5-fluoromethylfurfural; (3) - the sum of 5-BMF and 5-FMF concentrations

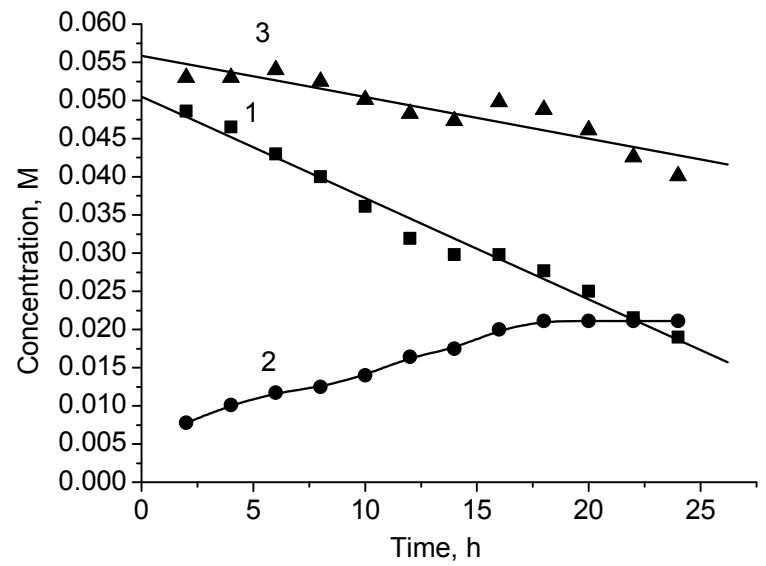

Fig. 3. Time dependence of 5-chloromethylfurfural into 5-fluoromethylfurfural conversion. $80{ }^{\circ} \mathrm{C}, 0.01 \mathrm{M}$ 18-crown-6 concentration. (1)-5-chloromethylfurfural (initial concentration $0.05 \mathrm{M}$ ); (2)-5-fluoromethylfurfural; (3) - the sum of 5-CMF and 5-FMF concentrations 


\section{The spectral data for 5-fluoromethylfurfural.}

${ }^{1} \mathrm{H}$ NMR spectral data $\left(600 \mathrm{MHz}, \mathrm{CDCl}_{3}\right) . \delta$, ppm: $5.4\left(\mathrm{~d} 2 \mathrm{H},-\mathrm{CH}_{2^{-}}, \mathrm{J}_{\mathrm{H}-\mathrm{F}}=48 \mathrm{~Hz}\right), 6.7(\mathrm{~d} / \mathrm{d} 1 \mathrm{H}$, $\left.\mathrm{CH}_{\text {fur, }}, \mathrm{J}_{3 \mathrm{H}-\mathrm{F}}=1.38 \mathrm{~Hz}, \mathrm{~J}^{2}{ }_{3 \mathrm{H}-4 \mathrm{H}}=3.60 \mathrm{~Hz}\right), 7.3\left(\mathrm{~d} / \mathrm{d} 1 \mathrm{H}, \mathrm{CH}_{\text {fur }}, \mathrm{J}^{2}{ }_{4 \mathrm{H}-\mathrm{F}}=1.38 \mathrm{~Hz}, \mathrm{~J}^{2}{ }_{3 \mathrm{H}-4 \mathrm{H}}=3.54 \mathrm{~Hz}\right)$, 9.7 (s 1H, CHO).

${ }^{13} \mathrm{C}$ NMR spectral data $\left(600 \mathrm{MHz}, \mathrm{CDCl}_{3}\right) . \delta$, ppm: $178.2\left(\mathrm{~s} \mathrm{C}_{1}\right), 154.5\left(\mathrm{~d} \mathrm{C}_{5}, \mathrm{~J}_{\mathrm{C}-\mathrm{F}}=18.5 \mathrm{~Hz}\right), 148\left(\mathrm{~s} \mathrm{C}_{2}\right)$, $121.5\left(\mathrm{~s} \mathrm{C}_{3}\right), 113.2\left(\mathrm{~d} \mathrm{C}_{4}, \mathrm{~J}_{\mathrm{C}-\mathrm{F}}^{2}=6 \mathrm{~Hz}\right), 75.5\left(\mathrm{~d} \mathrm{C}_{6}, \mathrm{~J}_{\mathrm{C}-\mathrm{F}}^{2}=166.2 \mathrm{~Hz}\right)$.

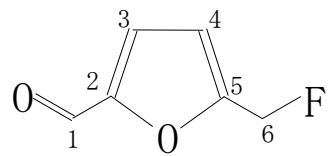

The observed spin-spin coupling constant for fluoromethyl group $\mathrm{J}_{\mathrm{H}-\mathrm{F}}^{2}=48 \mathrm{~Hz}$ is in agreement with the typical values for this group $[12,13]$.

Mass-spectrum, $70 \mathrm{eV}, \mathrm{m} / z$ (rel. int.): $128[\mathrm{M}]^{+}(100), 127[\mathrm{M}-\mathrm{H}]^{+}$(75), $110[\mathrm{M}-\mathrm{F}]^{+}$(3), $99[\mathrm{M}-\mathrm{CHO}]^{+}$ (35), $81[\mathrm{M}-\mathrm{CHO}-\mathrm{F}]^{+}$(3), 80 (3), 71 (45), 70 (26), 69(23), 53(15), 52(20), 51 (100), 50(50), 49(10).

Chemical properties. B.p. $98{ }^{\circ} \mathrm{C}(0.2 \mathrm{~mm} \mathrm{Hg})$. The substance is stable in solutions of $1: 1$ wateracetonitrile at $60^{\circ} \mathrm{C}$ during one hours, and with $0.01 \mathrm{M}$ of $\mathrm{HCl}$ or $\mathrm{NaOH}$ additives in the same solution at $25{ }^{\circ} \mathrm{C}$ during 5 hours. On the other hand, the subctance may spontaneously resinify when storing even in a refrigerator at $-5 \div-10{ }^{\circ} \mathrm{C}$ durind a week. Purification of crude 5-FMF by vacuum distillation was also complicated by its resinification. Such a behavior of the compound makes questionable the possibility of its commercial production $[14,15]$. Instability of the compound may be ascribed to autocatalytic origin of resinification by HF in non-aqueous media. Nevertheless, 40 and more mol. \% preparative yields of the product were attained.

The obtained results show that 5-fluoromethylfurfural can be obtained with a good yield attained $40-60 \mathrm{~mol}$. \% by interaction of 5-chloro- and 5-bromomethylfurfural with potassium bifluoride catalyzed by 18 -crown- 6 in acetonitrile medium, but the problem of its stability requires to be solved.

\section{References}

1. Popkov S.V. and Kuzenkov A.V. Synthesis of trifluoromethylsubstituted heteroaromatic aldehydes Rus. Chem. Bull., International Edition 2005. Vol. 54. P. 1672-1674.

2. Kenneth L., Kirk J. Fluorine in medicinal chemistry: Recent therapeutic applications of fluorinated small molecules. J. of Fluorine Chem. 2006. Vol. 127. P. 1013-1029.

3. Serdyuk O., Butin A., Abaev V. Synthesis of fluoroalkylfurans and perfluoroalkylfurans. J. of Fluorine Chem. 2010. Vol. 131. P. 296-319.

4. http://www.chemindustry.com/chemicals/054091544.html.

5. http://www.chemspider.com/Chemical-Structure.10144635.html.

6. Chernyak M.Yu., Tarabanko V.E., Sokolenko V.A., Morozov A.A. Synthesis of 5-fluoromethylfurfural from 5-bromomethylfurfural in presence of dibenzo-24-crown-8 // Chemistry of Plant Raw Material 2012. Vol. 3. P. 223-224. (In Russ.)

7. Hiraoka M. Crown Compounds. Their Characteristics and Applications, Elsevier Scientific Publishing Company, New York, 1982. 
8. Liotta C.L., Harris H.P. Chemistry of naked anions. I. Reactions of the 18-crown-6 complex of potassium fluoride with organic substrates in aprotic organic solvents // J. Am. Chem. Soc. 1974. Vol. 96. P. 2250-2253.

9. Shirinian V.Z., Shimkin A.A., Mailyan A.K., Leonova E.S. and Krayushki M.M. Convenient synthesis of diarylpropargyl alcohols // Mendeleev Commun. 2011. Vol. 21. P. 339-340.

10. Tarabanko V.E., ChernyakM.Yu., Smirnova M.A.Method of producing 5-bromomethylfurfural. RU Patent 2429234 (2011). (In Russ.)

11. http://www.orgsyn.org/orgsyn/orgsyn/prepContent.asp?prep=cv2p0393.

12. Timothy D.W., High-Resolution NMR Techniques in Organic chemistry, Pergamon, New York, 1999.

13. Pretsch E., Bullmann P., Affolter C. Structure determination of organic compounds, Springer, New York, 2006.

14. http://www.kingstonchem.com/pro_result/?id=118708.

15. http://www.chembuyersguide.com/cas/9/94043-06-8.html. 